\title{
The Effectiveness of Flipbook of Science (Fos) Multimedia on Elementary School Students Science Education
}

\author{
Muhammad Irfan ${ }^{1}$, Lutfi B ${ }^{2}$, Ulyawati ${ }^{3}$ \\ m.irfan@unm.ac.id ${ }^{1}$, lutfi.b@unm.com², Ulyawati1234@gmail.com ${ }^{3}$ \\ Universitas Negeri Makassar ${ }^{1,2,3}$
}

\begin{abstract}
This study aims to determine: the effectiveness of Flipbook of Science (FOS) multimedia in improving student learning outcomes in science subjects in elementary schools. This study uses a Pre- Test Post-Test Control Group Design. The instruments used were observation, questionnaires and tests, and analyzed with quantitative descriptive analysis. This study uses the effectiveness test by calculating the posttest, students' responses, and students' learning activities and considering the value of N-Gain. Based on the data obtained to see the effectiveness of FOS multimedia products, Based on the calculation of the average Post-Test, Student Responses, and learning activities as well as seeing the high N-Gain grades so that this product is in the category of very effectively used to improve student learning outcomes in science learning. So that with the results of this study can be used as a learning facility to improve the quality of learning. To add references and to become an alternative media in implementing effective learning methods, as well as being an innovation in the learning process, especially in elementary schools.
\end{abstract}

Keywords: Multimedia FOS, Learning Outcomes, Science

\section{Introduction}

In the 21 st century, the development of Information and Communication Technology (ICT) which has been sophisticated (sophisticated) has penetrated into various fields of life. The sophistication of ICT technology has made information from various parts of the world easier and faster to be accessed by anyone and wherever he is. These changes in the era of the industrial revolution made it a challenge to prepare quality Human Resources (HR).

To prepare quality human resources, one of the ways can be pursued through education, especially formal education. Schools as formal educational institutions must improve the quality of education with physical, intellectual and spiritual development as stated in the Law of the Republic of Indonesia Number 20 of 2003 concerning the National Education system Chapter II Article 3.

The regulation explains that in improving quality human resources there needs to be a conscious and planned effort in realizing an atmosphere of learning and learning process that can activate or develop their (students) potential. This can be done by means of the teacher must play an important role in managing learning (learning management) in order to be optimal.

The management of learning in order to be optimal is regulated in the Republic of Indonesia Government Regulation No. 17 of 2010 concerning the management and administration of education, the second part is basic education article 67 paragraph 1, namely education in elementary / MI or other forms of equivalent where one of its functions provides an introduction to knowledge knowledge and technology. Related to this regulation, the teacher has an important role to recognize and use technology so that science is not difficult to teach elementary school students. To teach students, one of the ways teachers do in conveying knowledge using technology is the use of multimedia in order to improve the quality of learning in the hope that student learning outcomes become more qualified [1].

The use of multimedia can be applied to Natural Sciences (IPA) subjects. The nature of the subject of Natural Sciences enables students to develop and make them understand about themselves and the world around them, as well as develop concepts, skills and attitudes that make students gain knowledge and discoveries and students can develop their scientific understanding as a tool to solve real-life problems, so that they include the character of technology [2], [3], [4]. So with the technological character applied to the learning of natural science, it allows the use of multimedia can be used in this study [5].

One of the learning media that has been developed is multimedia Flipbook of Science (FoS). Some research results suggest that the use of Flipbook multi media is very good for learning 
science in students both in primary and secondary schools, [6], [7] besides flipbooks are very effective in improving results student learning in elementary schools [8], [9]. Based on the findings of these studies, the authors are interested in knowing the effectiveness of FOS multimedia science materials in class IV at Telkom Makassar Elementary School, through a study entitled the effectiveness of elementary school student learning using FOS multimedia.

\section{Method}

The approach used in this study is a quantitative approach and uses experimental research methods with a pre-experimental one group (pretest-posttest) research design. This design was carried out five times a test to measure the effectiveness of FOS multimedia. This research is located on Jalan A.P. Pettarani No.4, Gunungsari Kelurahan Rappocini, Kota Makassar, at SD Telkom Makassar. Researchers have made observations at these locations and found problems that must be solved as discussed in the background.

The subjects in this study were selected based on the recommendations of their homeroom teacher. The research subjects are for individual trials of 3 students in the low, medium and high categories; small group trials consisting of 4 groups consisting of 12 people from class IVA, each group categorized as low, medium and high; and in the large group test conducted in class IVB, amounting to 26 students consisting of 17 male students and 9 female students, as well as class IV teachers namely Ayu Oktaviana, S.Pd and Irna, S.Pd. Determination of class IVB as a research sample using purposive sampling technique, which is based on considerations such as the recommendation of the guardian of class IV by considering the value of low science learning outcomes

\subsection{Quantitative Data Analysis}

Quantitative data were obtained from the results of the assessment of user responses. At this stage of data analysis, the assessment data uses a questionnaire. Data assessment results using a questionnaire, obtained from the responses of teachers and students. Questionnaire scores were performed using a Likert scale.

\subsubsection{Test the effectiveness of flipbook multimedia}

The assessment data uses the results of the pretest and posttest, student learning activities, and student responses during large group tests. The effectiveness categories are as follows:

Table 1. Categories of Multimedia Effectiveness

\begin{tabular}{cc}
\hline Nilai & Kategori \\
\hline $76 \%-100 \%$ & Very effectiv \\
\hline $51 \%-75 \%$ & Effectiv \\
\hline $26 \%-50 \%$ & Less effective \\
\hline $0-25 \%$ & Ineffective \\
\hline
\end{tabular}

Source: Arikunto [10]

\subsubsection{Uji N-Gain}

$\mathrm{N}$-gain test is performed to determine the strength of the increase in score of student learning outcomes. To see the N-gain in each group used an equation according to Meltzer (Khamzawi, 2015): 
$<g>=\frac{(\text { post test score })-(\text { pre test score })}{(\text { maksimum score })-(\text { pre test score })}$

The N-gain results obtained will be categorized based on the following table:

Table 4. N-gain categories

\begin{tabular}{cc}
\hline Kategori & N-gain \\
\hline High & $(<g>) \geq 0,70$ \\
Is & $0,70>(<g>) \geq 0,30$ \\
Low & $(<g>)<0,30$ \\
\hline
\end{tabular}

Source: Hake [11]

The assessment data uses the results of the pretest and posttest, student learning activities, and student responses during large group tests. The effectiveness category as follows $\mathrm{N}$-gain test is carried out to determine the strength of the increase in the score of student learning outcomes.

\section{Results and Discussion}

\subsection{Result}

This research activity has been carried out starting in September 2018, which is based on twelve aspects of observation, namely the SD Telkom learning program has used digital content but the implementation of the use of technology is still not effectively applied in this school. So that the use of media in the classroom has not been maximized, so the learning program is still teacher centered. In addition, the material from BSE has not addressed the problems in learning at Telkom Elementary School due to differences in student learning speeds. So to overcome this, the researchers tested the effectiveness of FOS multimedia products.

From the results of discussions with the homeroom teacher, 3 materials were selected in natural science subjects, namely the parts and functions of animal and plant bodies, the life cycle of living things and their preservation efforts and styles. The selection of the three materials is based on material characteristics that are difficult for students to understand. this is reinforced by the questionnaire data identifying the needs of students which is $76 \%$ answered the learning is quite difficult.

In implementation, the product is in the form of multimedia FOS. There are three types of trials conducted, namely individual trials consisting of 3 IVA class students, small group trials consisting of 4 groups of 12 students, and large group trials consisting of 26 students in IVB classes. Both types of individual trials aim to determine perceptions about the practicality of multimedia flipbooks, before proceeding to small group trials which are then tested on large groups. Based on the effectiveness of FOS multimedia products, the results are in the following figure. 


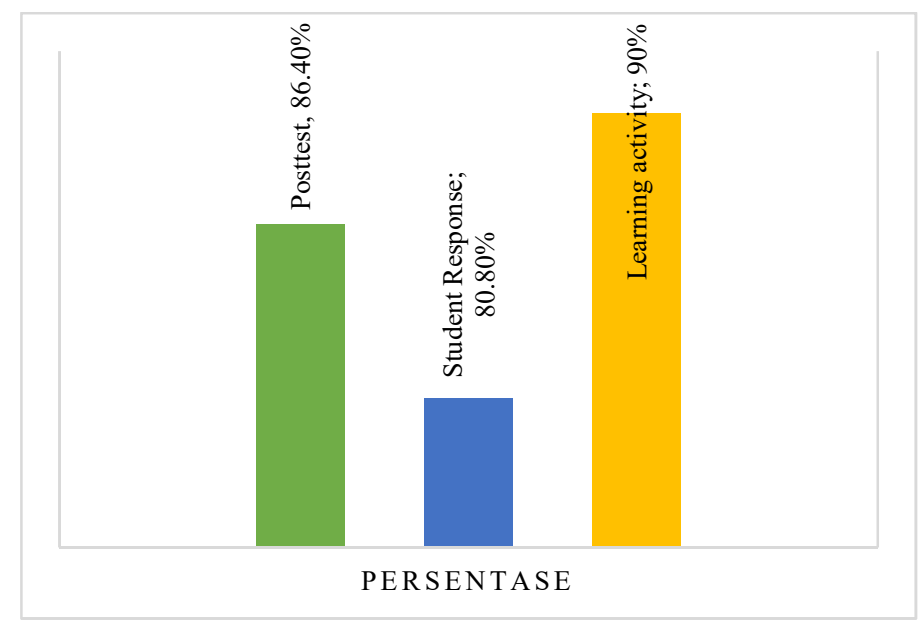

Fig 1. FOS Multimedia Effectiveness Acquisition Diagram

Based on the data obtained posttest grades IVB class students have a percentage of $86.4 \%$, student responses have a percentage of $80.8 \%$ and student learning activities have a percentage of $90 \%$ so that the overall overall data obtained is $90 \%$ with a very effective category.

\subsection{Discussion}

Based on the data obtained by the posttest value of IVB grade students has a percentage of $86.6 \%$, student responses have a percentage of $80.8 \%$ and student learning activities have a percentage of $90 \%$ so that the overall overall data obtained is $90 \%$ and $\mathrm{N}$-Gain is categorized high namely 0.72 so that the application of Multimedia FOS is in the category of very effectively used to improve student learning outcomes in science learning.

Related to the findings obtained by looking at research data, it can be explained that Based on Piaget's cognitive development level, the age range of 9 to 11 years is in concrete operations (concrete operations stages). this shows that students already have the ability to classify or the ability to group things according to the tasks given, using Multimedia FoS, students have been facilitated to do so as well as the suitability of the material to the development of student attitudes. According to Witherington, aged 9-12 years the development of individualist attitudes is formed. So as to minimize the attitude of these students multimedia flipbooks that can make students study in groups or in collaboration because learning activities and exercises are available and concept maps according to Helmawati concept maps help one learn faster and remember longer. So the concept map created helps students remember the key elements of a material. In addition, the application of theory according to Jensel [12] about audio in FoS multimedia uses instrumental music, intended to support information-intake (inserting information into the brain), which will help a person to the alpha state. The most helpful music in the learning process is music that does not contain words.

In addition, the implementation of learning theory in this FoS multimedia [13] such as behaviorime theory looks at the display of learning objectives, feedback that needs to be given, while related to the application of the theory of cognitivism seen in important information placed at the middle of layers such as concept map making and highlighted to be more interesting, information is displayed little by little to avoid excessive burden on memory, learning material is presented in accordance with student learning styles, and constructivism theory is learning needs to be interactive, examples of making interactive quizzes to support the use of multimedia flipbook and students have been able to control the course of learning. In accordance with the opinion [14] that the effectiveness of multimedia learning will increase if there are student-controlled facilities such as stop and play buttons. Based on the description above, it can be said that the application of FoS multimedia is effective to achieve learning objectives, namely providing mastery of concepts, improving skills and having a good attitude. 


\section{Conclusion}

Based on the results of research conducted, it is known that Multimedia Flipbook which is applied to grade IV elementary school children is effective to be applied in elementary school.

\section{References}

[1] M. Irfan, "Pengembangan multimedia interaktif untuk pembelajaran mata kuliah konsep dasar IPA I," Publ. Pendidik., vol. 2, no. 1, 2012.

[2] A. Oliveira and L. Pombo, "Teaching strategies mediated by technologies in the Edulab model: The case of mathematics and natural sciences," Int. J. Res. Educ. Sci., vol. 3, no. 1, pp. 88-106, 2017.

[3] G. O. Ilhan and S. Oruc, "Effect of the Use of Multimedia on Students' Performance: A Case Study of Social Studies Class.," Educ. Res. Rev., vol. 11, no. 8, pp. 877-882, 2016.

[4] A. Fonda and S. Sumargiyani, "THE DEVELOPING MATH ELECTRONIC MODULE WITH SCIENTIFIC APPROACH USING KVISOFT FLIPBOOK MAKER PRO FOR XI GRADE OF SENIOR HIGH SCHOOL STUDENTS,” Infin. J., vol. 7, no. 2, pp. 109-122, 2018.

[5] S. Purwo, "EFEKTIFITAS FLIPBOOK BERBASIS LITERASI DENGAN PENDEKATAN KONTEKSTUAL UNTUK SISWA SD,” Karya Ilm. Dosen, vol. 5, no. 1, 2019.

[6] I. Lestari, E. Ariyati, and R. Marlina, "Efektivitas Pembelajaran Kooperatif Berbantuan Flipbook terhadap Hasil Belajar Siswa pada Materi Virus di SMA," J. Pendidik. Dan Pembelajaran, vol. 5, no. 06, 2016.

[7] A. NINDY APSARI, "DEVELOPMENT OF E-BOOK USING KVISOFT FLIPBOOK MAKER TO TRAIN SCIENCE PROCESS SKILL FOR SENIOR HIGH SCHOOL STUDENTS IN CURRICULUM 2013," Inov. Pendidik. Fis., vol. 6, no. 3, 2017.

[8] N. N. Mulyaningsih and D. L. Saraswati, "Penerapan Media Pembelajaran Digital Book Dengan Kvisoft Flipbook Maker,” J. Pendidik. Fis., vol. 5, no. 1, pp. 25-32, 2017.

[9] I. Listyarini, H. J. Saputra, and M. A. K. Basyar, "PENGEMBANGAN MEDIA DIGITAL BOOK BERBASIS FLIPBOOK MAKER MATERI IPA KELAS V DI SEKOLAH DASAR," 2018.

[10] S. Hayati, A. S. Budi, and E. Handoko, "Pengembangan media pembelajaran flipbook fisika untuk meningkatkan hasil belajar peserta didik," in Prosiding Seminar Nasional Fisika (EJournal), 2015, vol. 4, pp. SNF2015-II.

[11] S. Hayati, A. S. Budi, and E. Handoko, "Pengembangan media pembelajaran flipbook fisika untuk meningkatkan hasil belajar peserta didik," in Prosiding Seminar Nasional Fisika (EJournal), 2015, vol. 4, pp. SNF2015-II.

[12] H. Hotimah and A. Muhtadi, "Pengembangan multimedia pembelajaran interaktif IPA untuk meningkatkan pemahaman siswa pada materi Mikroorganisme SMP," J. Inov. Teknol. Pendidik., vol. 4, no. 2, pp. 201-213, 2017.

[13] M. Rusli, D. Hermawan, N. N. Supuwiningsih, and S. Bali, Multimedia Pembelajaran yang Inovatif: Prinsip Dasar dan Model Pengembangan. Penerbit Andi, 2017.

[14] M. Rusli and Y. P. Atmojo, "Pointer Animation Implementation at Development of Multimedia Learning of Java Programming.," J. Educ. Pract., vol. 6, no. 28, pp. 119-127, 2015. 